\title{
Analysis of the SLC4A1 gene in three Mexican patients with hereditary spherocytosis: Report of a novel mutation
}

\author{
Josefina Y. Sánchez-López ${ }^{1}$, Ana L. Camacho-Torres ${ }^{1}$, Bertha Ibarra ${ }^{1,2}$, Jesús A. Tintos ${ }^{1,2}$ \\ and Francisco J. Perea ${ }^{1}$ \\ ${ }^{1}$ División de Genética, Centro de Investigación Biomédica de Occidente, \\ Instituto Mexicano del Seguro Social, Guadalajara, Jalisco, Mexico. \\ ${ }^{2}$ Centro Universitario de Ciencias de la Salud, Universidad de Guadalajara, Guadalajara, Jalisco, Mexico.
}

\begin{abstract}
We analyzed the SLC4A1 gene in three Mexican patients with Hereditary Spherocytosis (HS). The promoter and all 20 exons were investigated through heteroduplex analysis and DNA sequencing. No DNA changes were detected in one of the three patients. Two well-known polymorphisms, Memphis I and the Diego-a blood group, were detected in another one. In the third, the HS phenotype could be explained by the novel 1885_1888dupCCGG mutation found in heterozygosis. This frameshift mutation is predicted to result in a truncated and unstable protein lacking normal functions.
\end{abstract}

Key words: hereditary spherocytosis, hemolytic anemia, SLC4A1 gene, AE1 protein, band 3.

Received: July 17, 2009; Accepted: August 17, 2009.

Hereditary spherocytosis (HS) is a variably severe form of hemolytic anemia, caused by defects in the components of red cell membranes. It is characterized by the presence of spherical, dense and osmotically fragile red cells, which are selectively trapped in the spleen (Gallagher, 2005).

Spectrins, ankyrins, 4.2 protein and anion exchanger 1 (AE1) are the main defective proteins in subjects with HS (Delaunay, 2002). In a few studies of HS in Mexico, the main defective proteins observed were spectrins and AE1 (Sánchez-López et al., 2003).

The SLC4A1 gene (solute carrier family 4, anion exchanger, member 1) belongs to the anion-exchanger family, and encodes two AE1 isoforms, namely erythroid (eAE1) and renal (rAE1). The eAE1 isoform is a glycoprotein of 911 amino acids with three domains: (1) the N-terminal cytoplasmic domain (residues 1-403), containing the binding sites for hemoglobin and some cytosolic enzymes, which acts as a membrane anchorage site for the red cell skeleton through its interactions with ankyrin, and 4.1 and 4.2 proteins; (2) the transmembrane domain (residues 404-882), which has 14 segments spanning the lipid bilayer and is responsible for $\mathrm{Cl}^{-} / \mathrm{HCO}_{3}{ }^{-}$exchange; and (3) a short cytoplasmic C-terminal domain (residues 883-911), containing binding sites for carbonic anhydrase II. The rAE1

Send correspondence to Francisco Javier Perea Díaz. División de Genética, Centro de Investigación Biomédica de Occidente, IMSS, Sierra Mojada n. 800, Col. Independencia. 44340 Guadalajara, Jalisco, México. E-mail: javier_perea_diaz@yahoo.com.mx. isoform lacks the first 65 amino acids of the $\mathrm{N}$-terminal domain, since it is transcribed from a second promoter located in intron 3 of the SLC4A1 gene (Alper, 2006; Delaunay, 2002).

Several mutations of SLC4A1 have been described that result in distal renal tubular acidosis (Bruce et al., 1997; Jarolim et al., 1998; Yenchitsomanus et al., 2003, 2005). Other SLC4A1 mutations result in red blood cell abnormalities, HS and southeastern Asian ovalocytosis (Miraglia del Giudice et al., 1997, Ranney et al., 1990, Wrong et al., 2002). Most mutant HS alleles generate unstable mRNA, and thus, reduced (or absent) mutant eAE1 polypeptide. Nevertheless, patients with HS have an apparently normal renal acidification phenotype (Alper, 2006). SLC4A1 polymorphisms have also been described (Jarolim et al., 1992, Miraglia del Giudice et al., 1997), including the Diego blood group (Baleotti et al., 2003), some of which are involved in the antigenicity of blood groups.

In this work, we present an analysis of the SLC4A1 gene in three Mexican patients with HS, previously identified with combined AE1 deficiency. In Subject I, there was a 32\% reduction in AE1 and 39\% in the 4.2 protein, in Subject II, an $18.5 \%$ reduction in AE1, and in Subject III a 37\% reduction in $\mathrm{AE} 1$ and $49 \%$ in spectrins.

The salting-out method (Miller et al., 1988) was used for DNA extraction, and the polymerase chain reaction (PCR) for amplifying the promoter region and 20 exons (21 fragments) of the $S L C 4 A 1$ gene, this with the previously described primers and appropriate PCR conditions (Miraglia 
del Giudice et al., 1997). Each PCR product included complete exon and splice sites, on which heteroduplex analysis was performed as previously described (Zhang and Minoda, 1996). Electrophoretically abnormal products were sequenced with an ABI-PRISM 310 sequencer, using a BigDye Terminator reaction kit (v. 3.1; Applied Biosystems, Foster City, CA, USA).

Heteroduplex analysis revealed six abnormal electrophoretic fragments in Subject I (exons 4, 11, 12, 13, 19, and 20), four in Subject II (exons 11, 13, 17, and 20) and six in Subject III (exons 3, 7, 9, 11, 14, and 16).

In subject I, two heterozygous substitutions were detected by DNA sequencing, namely a $166 \mathrm{~A} \rightarrow \mathrm{G}$ in exon 4 and a $2561 \mathrm{C} \rightarrow \mathrm{T}$ in exon 19 , corresponding to the known Memphis I (Lys56Glu) and Diego-a blood group (Pro854Leu) polymorphisms, respectively; these changes were identified in the subject's mother, also in heterozygosis. No further DNA changes were revealed on sequencing the remaining SLC4A1 exons. In Subject II no changes were observed in all the 20 sequenced exons. Six exons with abnormal electrophoretic patterns were sequenced from Subject III, and a CCGG duplication of nucleotides $1885-1888$ at exon 14 was found in the heterozygous state. The patient's father and brother did not carry this mutation, whereas the mother was not available for study purposes.

Two Memphis variants have been described. Memphis I (Lys56Glu) is relatively common in native Americans (frequency up to $25 \%$ ), Japanese (29\%) and African Americans (15\%) (Ideguchi et al., 1992, Jarolim et al., 1992, Ranney et al., 1990), besides Mexicans (11\%) (Camacho-Torres et al., 2006). The Memphis II variant carries Lys56Glu and Pro854Leu polymorphisms (Bruce et al., 1994; Spring et al., 1992). The Diego-a $\left(\mathrm{Di}^{\mathrm{a}}\right)$ allele (Pro854Leu) is the result of a $2561 \mathrm{C} \rightarrow \mathrm{T}$ change in exon 19 (Bruce et al., 1994), and is common in native South Americans (up to 54\%), Mexicans (20.4\%), Japanese (12\%), Koreans $(6.4 \%-14.5 \%)$ and Chinese $(5 \%)$ but is rare in Caucasians $(0.01 \%)$. It is considered a genetic marker for people of East Asian origin, therefore significant for anthropological studies (Baleotti et al., 2003, Junqueira and Castilho, 2002). In most cases the $\mathrm{Di}^{\mathrm{a}}$ allele (Pro854Leu) is linked to Memphis I polymorphism (Lys56Glu) (Bruce et al., 1994; Spring et al., 1992), although an unlinked form was observed in four out of 70 Amazonian Indians (Baleotti et al., 2003). Studies in various populations are required to verify the occurrence of individuals with the $2561 \mathrm{C} \rightarrow \mathrm{T}\left(\mathrm{Di}^{\mathrm{a}}\right.$ allele) not linked to Memphis I polymorphism. The fact that both changes were maternally inherited in Subject I is suggestive that they are in cis, thus characterizing the Memphis II variant. Anyway, these polymorphisms are not related to the HS phenotype of Subject I. No HS causative SLC4AI mutation in this subject was observed, even after sequencing exons revealed as negative by heteroduplex analysis. Another gene might be contributing to the combined AE1 and 4.2 protein deficiency in this Subject (e.g., EPB42). Nevertheless, a mutation, such as a large deletion and undetectable by sequencing, cannot be excluded, neither in this patient nor in Subject II, for whom no changes were revealed on sequencing all the SLC4A1 exons. There are at least $11 \mathrm{Alu}$ sequences which would facilitate mispairing and unequal crossing over.

In Subject III, the novel mutation 1885 1888dupCCGG apparently gives rise to the HS phenotype. The duplication in the sixth trans-membrane segment leads to a frameshift and predicts 57 different amino acids being encoded from codon 580 up to a stop codon at position 637. According to sequence analysis (NCBI Accession NM_000342.3), the truncated protein is probably unstable and without a normal function. A review of the literature (HGMD2009) showed 52 different SLC4A1 mutations to be HS causative, and about 20 frameshift mutations, as that described herein.

\section{Acknowledgments}

This work was supported by a grant from CONACYT No. 31008-M.

\section{References}

Alper SL (2006) Molecular physiology of SLC4 anion exchangers. Exp Physiol 91:153-161.

Baleotti W, Rios M, Reid ME, Fabron A, Pellegrino J, Saad ST and Castilho L (2003) A novel DI*A allele without the Band 3 Memphis mutation in Amazonian Indians. Vox Sang 84:326-330

Bruce LJ, Ansteen DJ, Springll FA and Tanner MJ (1994) Band 3 Memphis variant II. Altered stilbene disulfonate binding and the Diego (Dia) blood group antigen are associated with the human erythrocyte band 3 mutation Pro854 $\longrightarrow$ Leu. J Biol Chem 269:16155-16158.

Bruce LJ, Cope DL, Jones GK, Schoefield AE, Burley M, Povey S, Unwin RJ, Wrong O and Tanner MJ (1997) Familial distal renal tubular acidosis is associated with mutations in the red cell anion exchanger (Band 3, AE1) gene. J Clin Invest 100:1693-1707.

Camacho-Torres AL, Sánchez-López JY, Mesa-Cornejo VM, Ibarra B and Perea-Díaz FJ (2006) Polymorphism analysis of G199A, Ncol in ANK1 and Memphis I in SLC4A1 genes in Mexican healthy individuals and subjects affected with hereditary spherocytosis. Gac Méd Méx 142:435-437.

Delaunay J (2002) Molecular basis of Red Cell Membrane Disorders. Acta Haematol 108:210-218.

Gallagher PG (2005) Red Cell Membrane Disorders. Hematology Am Soc Hematol Educ Program :13-8.

Ideguchi H, Okubo K, Ishikawa A, Futata Y and Hamasaki N (1992) Band 3-Memphis is associated with a lower transport rate of phosphoenolpyruvate. Br J Haematol 82:122-125.

Jarolim P, Rubin HL, Zhai S, Sahr KE, Liu SC, Mueller TJ and Palek J (1992) Band 3 Memphis: A widespread polymorphism with mobility of erythrocyte band 3 protein caused by substitution AAG-GAG (lys-glu) in codon 56. Blood 80:1592-1598. 
Jarolim P, Shayakul C, Prabakaran D, Jiang L, Stuart-Tilley A, Rubin HL, Simova S, Zavadil J, Herrin JT, Brouillette J, et al. (1998) Autosomal dominant distal renal tubular acidosis is associated in three families with heterozygosity for the $\mathrm{R} 589 \mathrm{H}$ mutation in the $\mathrm{AE} 1$ (band 3) $\mathrm{Cl}-/ \mathrm{HCO} 3$ - exchanger. J Biol Chem 273:6380-6388.

Junqueira PC and Castilho L (2002) The history of the Diego blood group. Rev Bras Hematol Hemoter 24:15-23.

Miller SA, Dykes DD and Polesky HF (1988) A simple salting out procedure for extracting DNA from human nucleated cells. Nucleic Acids Res 16:1215-1216.

Miraglia del Giudice E, Vallier A, Maillet P, Perrota S, Cutillo S, Iolascon A, Tanner MJ, Delaunay J and Alloisio N (1997) Novel band 3 variants (bands 3 Foggia, Napoli I and Napoli II) associated with hereditary spherocytosis and band 3 deficiency: Status of the D38A polymorphism within the EPB3 locus. Br J Haematol 96:70-76.

Ranney HM, Rosenberg GH, Morrison M and Mueller TJ (1990) Frequencies of Band 3 variants of human red cell membranes in some different populations. $\mathrm{Br} \mathrm{J}$ Haematol 76:262-267.

Sánchez-López JY, Camacho AL, Magaña MT, Ibarra B and Perea FJ (2003) Red Cell Membrane protein deficiencies in Mexican patients with Hereditary Spherocytosis. Blood Cell Mol Dis 31:357-359.

Spring FA, Bruce LJ, Anstee DJ and Tanner MJ (1992) A red cell band 3 variant with altered stilbene disulphonate binding is associated with the Diego (Dia) blood group antigen. Biochem J 288:713-716.
Wrong O, Bruce LJ, Unwin RJ, Toye AM and Tanner MJ (2002) Band 3 mutations, distal renal tubular acidosis, and Southeast Asian ovalocytosis. Kidney Int 62:10-19.

Yenchitsomanus PT (2003) Human anion exchanger1 mutations and distal renal tubular acidosis. Southeast Asian J Trop Med Public Health 34:651-658.

Yenchitsomanus PT, Kittanakom S, Rungroj N, Cordat E and Reithmeier RAF (2005) Molecular mechanisms of autosomal dominant and recessive distal renal tubular acidosis caused by SLC4A1 (AE1) mutations. J Mol Gen Med 1:4962.

Zhang Q and Minoda K (1996) Detection of RB germline mutations using exon-by-exon heteroduplex analysis compared with SSCP. Yan Ke Xue Bao 12:151-157.

\section{Internet Resources}

National Center for Biotechnology Information (NCBI), http://www.ncbi.nlm.nih.gov/nuccore/170014726?ordinalp $\mathrm{os}=1 \&$ itool $=$ EntrezSystem2.PEntrez.Sequence.Sequence_ResultsPanel.Sequence_RVDocSum (August 2, 2009).

The Human Genome Mutation Database at The Institute of Medical Genetics in Cardiff (HGMD), http://www.hgmd.cf.ac.uk/ac/gene.php?gene = SLC4A1 (August 4, 2009).

Editor: Angela M. Vianna-Morgante

License information: This is an open-access article distributed under the terms of the Creative Commons Attribution License, which permits unrestricted use, distribution, and reproduction in any medium, provided the original work is properly cited. 